\title{
Trophic support promotes survival of bcl-x-deficient telencephalic cells in vitro
}

Kenneth S. Shindler ${ }^{1}$, Anne Marie R. Yunker ${ }^{1}$, Rael Cahn ${ }^{1}$, Jiping Zha ${ }^{2}$, Stanley J. Korsmeyer ${ }^{2}$ and Kevin A. Roth ${ }^{1,3}$

${ }^{1}$ Department of Pathology, Washington. University School of Medicine, St Louis, Missouri 63110, USA

2 Departments of Medicine and Pathology, Howard Hughes Medical Institute, Washington University School of Medicine, St Louis, Missouri 63110, USA

${ }^{3}$ corresponding author: Kevin A. Roth, M.D., Ph.D., Department of Pathology, Washington University School of Medicine, 660 South Euclid Avenue, Box 8118, St. Louis, MO 63110, USA. Tel: (314) 362-7449; fax: (314) 362-4096; e-mail: kroth@pathology.wustl.edu

Received 7.10.97; revised 17.3.98; accepted 2.6.98

Edited by C.J. Thiele

\section{Abstract}

Survival of immature neurons is regulated by $B c l-x_{L}$, as targeted disruption of $b c l-x$ significantly increases cell death in vivo and in vitro. Death of cultured bcl-x-deficient and wildtype telencephalic cells can be prevented by fetal calf serum or chemically-defined medium (ITS), suggesting trophic factors in these media potentiate survival through a pathway independent of $\mathrm{Bcl}-\mathrm{x}_{\mathrm{L}}$. Addition of trophic factors to basal medium revealed that insulin and insulin-like growth factors (IGFs), but not other trophic factors, reduced apoptosis of wild-type and bcl-x-deficient telencephalic cells. Antibodies raised against IGF-I receptors and wortmannin both attenuated the effects of IGF-I, indicating survival was mediated by IGF-I receptors and phosphatidylinositol 3'kinase signaling, whereas effects of ITS were only partially reduced by these agents. The survival promoting effects of ITS were reduced in cells lacking both $b c l-x$ and $b c l-2$, indicating $\mathrm{Bcl}-2$ plays a supportive role to $\mathrm{Bcl}-\mathrm{x}_{\mathrm{L}}$ in maintaining telencephalic cell survival. Furthermore, the ratio of expression of the pro-apoptotic bax gene to the anti-apoptotic bcl-2 gene was reduced in bcl-x-deficient cultures grown in ITS, suggesting that the interaction between these bcl-2 family members may, in part, regulate $\mathrm{a} \mathrm{Bcl}-\mathrm{x}_{\mathrm{L}}$ independent survival pathway. Finally, the pro-apoptotic bad gene does not appear to play a role in these interactions as targeted disruption of bad did not alter apoptosis in telencephalic cultures.

Keywords: Bcl-x; Bcl-2; Bax; insulin; insulin-like growth factors; apoptosis; telencephalon

Abbreviations: BDNF, brain-derived neurotrophic factor; CNS, central nervous system; CNTF, ciliary neurotrophic factor; DMEM, Dulbecco's Modified Eagle's Medium; EGF, epidermal growth factor; FCS, fetal calf serum; GDNF, glial-derived neurotrophic factor; IGF, insulin-like growth factor; $\alpha-\mathrm{IR}_{3}$, anti-IGF-I receptor antibody; ITS, insulin-, transferrin-, and selenium-containing medium; MAP, microtubule associated protein; NGF, nerve growth factor; NT, neurotrophin; PCD, programmed cell death; PI3K, phosphatidylinositol 3'-kinase; S.E.M., standard error of the mean

\section{Introduction}

Significant numbers of cells are eliminated by programmed cell death $(P C D)$ during nervous system development, with over $50 \%$ of neurons dying in some regions (Oppenheim, 1991). This death typically occurs by the process of apoptosis (Wyllie et al, 1980; Clarke, 1990). Classic studies of the nervous system have examined a period of PCD when neurons compete for limited amounts of trophic factors released by target tissues (Purves, 1986; Cowan et al, 1984; Levi-Montalcini, 1966; Oppenheim, 1991). However, a number of studies have demonstrated that widespread apoptosis occurs prior to target innervation in populations of immature neurons and neural precursor cells (Thomaidou et al, 1997; Galli-Resta and Ensini, 1996; Blaschke et al, 1996; Homma et al, 1994; Acklin and van der Kooy, 1993; Lance-Jones, 1982; Maruyama and D'Agostino, 1967). Although these cells are not yet dependent upon target-derived trophic factors, the possibility that survival of immature neurons and/or progenitor cells may be enhanced by non-target-derived trophic factors needs to be examined.

One gene that plays an important role in regulating survival of immature neurons prior to target innervation is $b c l-x$. Bcl-x is a member of a family of proteins which share sequence homology with Bcl-2 (Merry and Korsmeyer, 1997; Craig, 1995; Reed, 1994). Although $b c l-x$ can be alternatively spliced into $b c l-x_{L}$ or $b c l-x_{S}$, only $b c l-x_{L}$ is expressed in the mouse CNS (Krajewski et al, 1994; Boise et al, 1993; Gonzalez-Garcia et al, 1994). Bcl-X prevents apoptosis of many cell types, including immune cells and post-mitotic neurons (Gonzalez-Garcia et al, 1995; Boise et al, 1993; Frankowski et al, 1995). Targeted disruption of $b c l-x$ significantly increases apoptosis of immature neurons throughout the central nervous system (CNS), indicating that $\mathrm{BCl}-\mathrm{X}_{L}$ is necessary for the survival of these cells (Motoyama et al, 1995).

Primary cultures of E12 telencephalic cells have become a useful model in defining molecules important for early neuronal survival. Similar to neuroepithelial cells in vivo, wild-type E12 telencephalic cells cultured in basal medium can differentiate into neurons and/or die by apoptosis (Shindler et al, 1997). Furthermore, apoptosis in cultures of $b c l-x$-deficient $\left(b c l-x^{-1-}\right)$ neurons significantly increases compared to wild-type cultures (Shindler et al, 1997; Roth et al, 1996). Interestingly, apoptosis of wild-type and $b c /-x^{-1-}$ telencephalic cells is almost completely eliminated in cultures grown in basal medium supplemented with fetal calf serum (FCS) or in chemically-defined medium 
(ITS) containing a variety of compounds including insulin, transferrin, and selenium (Roth et al, 1996). These data suggest that factors present in these media promote survival of immature neurons.

In addition to $\mathrm{Bcl}-\mathrm{x}_{\mathrm{L}}$, other $\mathrm{Bcl}-2$ gene family members are important in controlling cell survival. Members such as Bcl-2, $\mathrm{Bcl}-\mathrm{w}$, and $\mathrm{Mcl}-1$ inhibit apoptosis and promote cell survival, whereas Bax, Bad, and Bak promote apoptosis (reviewed in Merry and Korsmeyer, 1997). Some Bcl-2 family members can form heterodimers (Sato et al, 1994; Chittenden et al, 1995; Yin et al, 1994; Sedlak et al, 1995), and the balance between anti-apoptotic and pro-apoptotic proteins is important in determining if a given signal results in apoptosis (Shindler et al, 1997; Krajewski et al, 1995; Oltvai and Korsmeyer, 1994; Oltvai et al, 1993; Sedlak et al, 1995). Therefore, ITS and FCS may promote cell survival in vitro by regulating expression of the $\mathrm{Bcl}-2$ gene family. For example, ITS and FCS may rescue $b c /-x^{-1-}$ telencephalic cells by promoting up-regulation of anti-apoptotic genes such as $b c /-2$ or down-regulation of pro-apoptotic genes such as bax.

In the present study, survival of E12 telencephalic cells treated with neurotrophic factors was examined. Potential signaling of these factors through activation of IGF-I receptors and phosphatidylinositol 3 '-kinase (PI3K) was examined by treating cultures with antibodies raised against IGF-I receptors $\left(\alpha-\mathrm{IR}_{3}\right)$ and wortmannin, a PI3K inhibitor. Cultures of $b c /-2^{-1-} / b c l-x^{-1-}$ telencephalic cells were used to determine if ITS can maintain cell survival in the absence of $b c /-2$, and expression of $b c l-2$ and bax mRNA were compared between cultures grown in basal medium or ITS. Furthermore, the role of bad was assessed in cultures of $\mathrm{bad}^{-1-}$ cells. Results indicate that IGF-I, IGF-II, and insulin reduce apoptosis of telencephalic cells, and that ITS medium may, in part, promote survival by altering the balance between $b c l-2$ and bax.

\section{Results}

\section{ITS and FCS prevent apoptosis of wild-type and bcl-x-deficient telencephalic cells}

Similar to results reported previously (Shindler et al, 1997), telencephalic cultures from E12 wild-type embryos grown for $48 \mathrm{~h}$ in basal medium (DMEM) contained differentiating neurons as determined by cellular morphology and expression of MAP2, a neuronal marker (data not shown). Cultures also contained a baseline level of cell death as $27.4 \pm 1.5 \%$ of cells (from 24 embryos) were apoptotic (Figure 1A) as determined by condensed and fragmented chromatin staining with bisbenzimide. Cultures from $b c /-x^{-1-}$ mice (21 embryos) contained significantly more apoptotic cells $(76.5 \pm 1.7 \%$ cells) (Figure $1 \mathrm{~A})$. Apoptosis of both wild-type and $b c /-x^{-1-}$ cells was significantly reduced in cultures grown in ITS or $1.0 \%$ FCS for $48 \mathrm{~h}$ (Figure $1 \mathrm{~A}$ ).

\section{IGF receptor ligands promote telencephalic cell survival independent of Bcl- $x_{L}$}

Since ITS and FCS have a dramatic survival promoting effect on cultured $b c /-x^{-1-}$ telencephalic cells, the ability of a variety of known neurotrophic factors to activate a $\mathrm{Bcl}-\mathrm{x}_{\mathrm{L}}$ independent anti-apoptotic pathway was examined. ITS contains a high
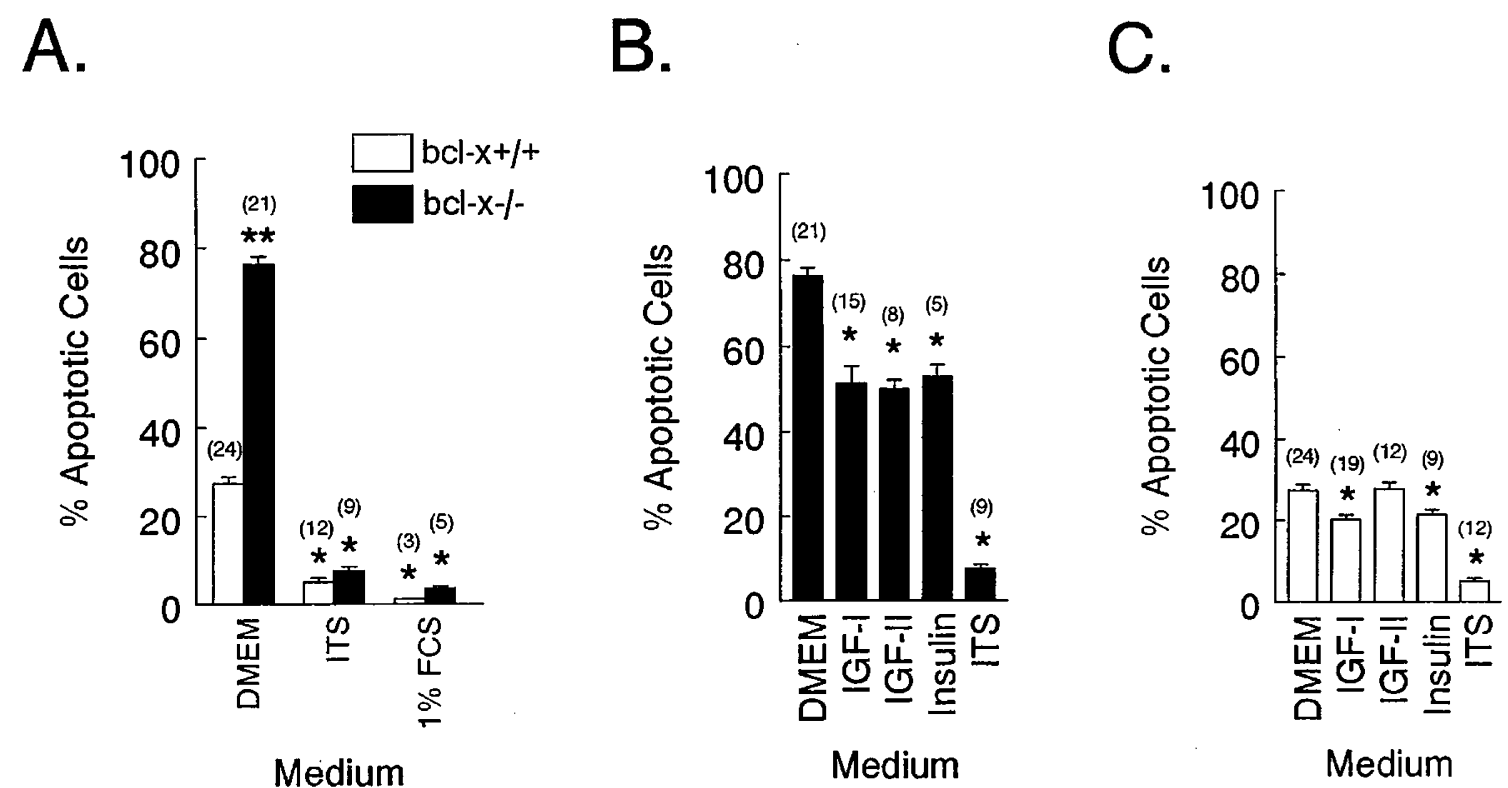

Figure 1 Enriched media, insulin, and insulin-like growth factors promote survival of wild-type $\left(b c l-x^{+/+}\right)$and $b c l-x$-deficient $\left(b c l-x^{-/-}\right)$E12 telencephalic cells in culture. (A) Chemically-defined medium containing insulin, transferrin, and selenium (ITS) and DMEM containing fetal calf serum (FCS) reduce the number of apoptotic cells as compared to cultures grown in DMEM. Data are expressed as mean percentage of cells with bisbenzimide-labeled condensed chromatin/total number of cells \pm S.E.M. Statistical significance $(P \leqslant 0.05)$ is represented by * for comparisons to corresponding cultures in DMEM and ** for comparisons of cultures grown in DMEM. B-C. Insulin $\left(5 \mu \mathrm{g} \mathrm{ml}^{-1}\right)$ and insulin-like growth factors (IGF) (100 $\left.\mathrm{ng} \mathrm{ml}^{-1}\right)$ decrease apoptosis of E12 cells from bcl-x ${ }^{-1-}(\mathrm{B})$ and $b c l-x^{+/+}(\mathbf{C})$ mice as compared to sister cultures in DMEM $\left({ }^{*}\right.$ denotes $\left.P \leqslant 0.05\right)$. Numbers in parentheses indicate the number of embryos examined in each condition 
concentration of insulin which may activate IGF receptors; therefore, the ability of IGF receptor ligands IGF-I, IGF-II, and insulin to promote survival of $b c /-x^{-1-}$ cells was tested. Each of these ligands added to basal medium produced a significant reduction of the number of dying $b c /-x^{-1-}$ telencephalic cells (Figure 1B). Although IGF receptor ligands increased survival, apoptosis still occurred in approximately $50 \%$ of $b c /-x^{-1-}$ cells grown in supplemented media, suggesting that additional factors may promote survival of $\mathrm{E} 12 \mathrm{bcl}-\mathrm{x}^{-1-}$ telencephalic cells. The effects of a number of neurotrophic factors were tested using concentrations of factors shown previously to have maximal effects on other neuronal cells (Ip et al, 1994; Lin et al, 1993; Lindholm et al, 1996; Knusel et al, 1990; Widmer and Hefti, 1994). Addition of $50 \mathrm{ng} \mathrm{ml}^{-1}$ nerve growth factor (NGF), $25 \mathrm{ng} \mathrm{ml}^{-1}$ brain-derived neurotrophic factor (BDNF), $25 \mathrm{ng} \mathrm{ml}^{-1}$ neurotrophin (NT)-3, $25 \mathrm{ng} \mathrm{ml}^{-1} \mathrm{NT}-4$, $25 \mathrm{ng} \mathrm{ml}^{-1}$ ciliary neurotrophic factor (CNTF), $25 \mathrm{ng} \mathrm{ml}^{-1}$ glial-derived neurotrophic factor (GDNF), or $25 \mathrm{ng} \mathrm{ml}^{-1}$ epidermal growth factor (EGF) did not increase $b c /-x^{-1-}$ telencephalic cell survival (data not shown).

The above results suggest that IGF receptor ligands can promote telencephalic cell survival through a $\mathrm{Bcl}-\mathrm{x}_{\mathrm{L}}$ independent process. To determine whether these factors promote survival in the presence of $\mathrm{Bcl}-\mathrm{x}_{\mathrm{L}}$, factors were added to wild-type telencephalic cell cultures and results were compared with those presented for $b c /-x^{-1-}$ cells. Similar to $b c /-x^{-1-}$ cultures, insulin and IGF-I significantly increased wild-type cell survival (Figure 1C). IGF-II failed to increase wild-type cell survival. NGF, BDNF, NT-3, NT-4/5, CNTF, GDNF, and EGF also failed to affect telencephalic cell survival (data not shown).

\section{IGF-I promotes telencephalic survival through the IGF-I receptor and PI3K signaling}

IGF-I has been shown previously to promote survival in some neuronal systems by activating the IGF-I receptor and PI3K signaling pathway (Singleton et al, 1996a,b; Matthews and Feldman, 1996; D'Mello et al, 1997). To determine if these pathways are similarly involved in IGF-I mediated survival of E12 telencephalic cells, cultures grown in $100 \mathrm{ng} \mathrm{ml}^{-1}$ IGF-I were treated with either $2 \mu \mathrm{g} \mathrm{ml}^{-1} \alpha-\mathrm{IR}_{3}$ or $100 \mu \mathrm{M}$ wortmannin, concentrations which have been used previously to block IGF-I receptor activation and PI3K, respectively (Matthews and Feldman, 1996; D'Mello et al, 1997). Differences in apoptosis were not found among wild-type or $b c /-x^{-l-}$ E12 telencephalic cultures grown in DMEM, DMEM and $\alpha-\mathrm{IR}_{3}$ or DMEM and wortmannin (data not shown). Cultures of $b c /-x^{-1-}$ cells grown in the presence of both IGF-I and either $\alpha-\mathrm{IR}_{3}$ or wortmannin contained significantly more apoptosis than cultures grown in IGF-I alone $(P \leqslant 0.05)$, whereas levels of apoptosis were not different from cultures grown in unsupplemented DMEM $(P \geqslant 0.05$; Figure $2 \mathrm{~A})$. Similarly, in wild-type cultures there were no differences in apoptosis between cultures grown in unsupplemented DMEM and cultures treated with both IGF-I and $\alpha-\mathrm{IR}_{3}$ or with IGF-I and wortmannin ( $P \geqslant 0.05$ Figure $2 \mathrm{~A})$.

ITS contains high concentrations of insulin that may be able to activate IGF-I receptors. To determine if IGF-I
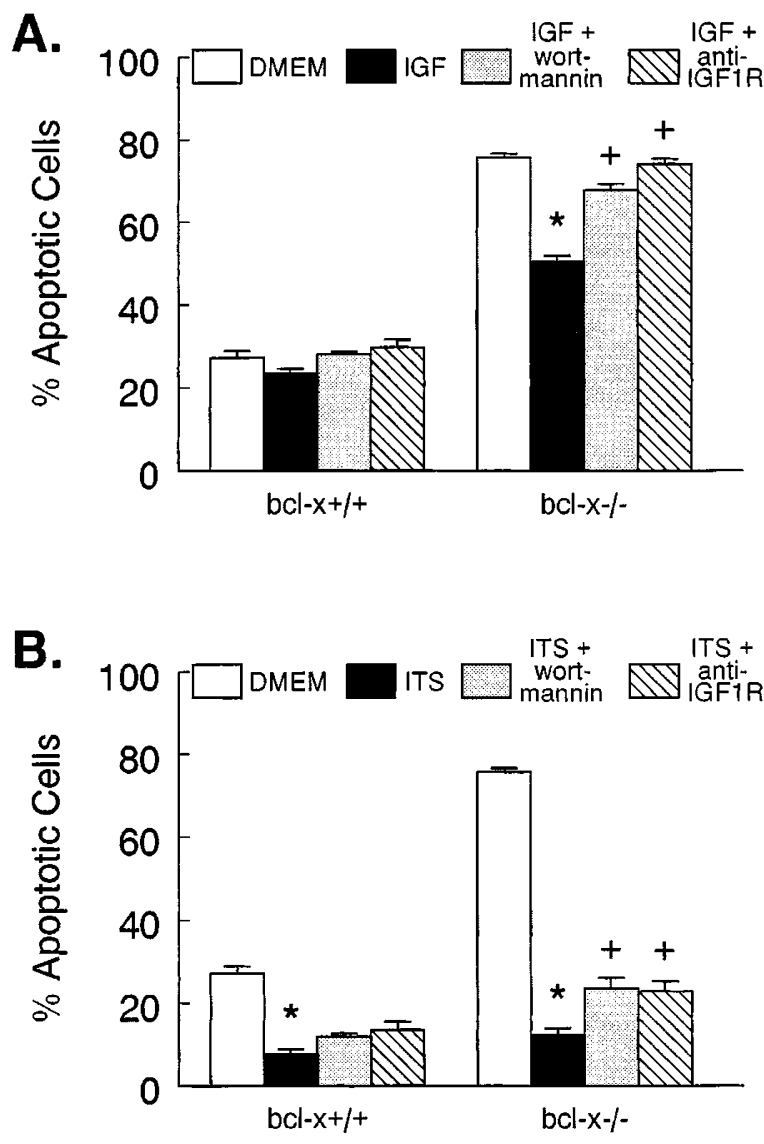

Figure 2 Wortmannin or antibodies raised against IGF-I receptors attenuate survival of $b c /-x^{-I}-\mathrm{E} 12$ telencephalic cells in media containing IGF-I or ITS. Addition of antibodies raised against IGF-I receptors $\left(\alpha-I R_{3}\right)$ or wortmannin, an inhibitor of PI3K, attenuates survival of $b c /-x^{-1-}$ cells grown in DMEM supplemented with IGF-I (A) or grown in ITS (B). Data are expressed as mean percentage of cells with bisbenzimide-labeled condensed chromatin/total number of cells \pm SEM. Statistical significance $(P \leqslant 0.05)$ is represented by * for comparisons to corresponding cultures in DMEM and + for comparisons of cultures grown in ITS or IGF-I

receptor activation and $\mathrm{PI} 3 \mathrm{~K}$ signaling are also involved in ITS mediated telencephalic survival, wild-type and $b c /-x^{-/-}$ cultures grown in ITS were treated with $\alpha-\mathrm{IR}_{3}$ or wortmannin. $b c l-x^{-1-}$ cultures grown in ITS supplemented with $\alpha-\mathrm{IR}_{3}$ or wortmannin contained significantly more apoptotic cells than cultures grown in unsupplemented ITS ( $P \leqslant 0.05$; Figure $2 \mathrm{~B})$. Wild-type ITS cultures treated with $\alpha-\mathrm{IR}_{3}$ or wortmannin also showed a tendency toward increased apoptosis as compared to ITS cultures, but this difference was not statistically significant $(P \geqslant 0.05$; Figure $2 \mathrm{~B})$. However, apoptosis was still significantly lower in both wild-type and $b c /-x^{-l-}$ cultures grown in ITS with $\alpha$-IR3 or wortmannin as compared to cultures grown in DMEM $(P \leqslant 0.05$; Figure $2 \mathrm{~B})$.

\section{bcl-2 promotes survival of bcl-- ${ }^{-1-}$ telencephalic cells in ITS}

Insulin, IGF-I, and IGF-II reduced apoptosis of E12 $b c /-x^{-/-}$ telencephalic cells, although ITS and FCS appeared more 
effective in promoting cell survival. In the absence of $\mathrm{Bcl}-\mathrm{x}_{\mathrm{L}}$, other anti-apoptotic members of the Bcl-2 family might promote telencephalic cell survival. We hypothesized that ITS may reduce apoptosis of E12 telencephalic cells by regulating $b c l-2$, which could then function in place of $\mathrm{Bcl}-\mathrm{x}_{\mathrm{L}}$ to promote cell survival. Mice carrying a targeted disruption of $b c l-2$ were bred to $b c l-x$-deficient mice to test this possibility. Double heterozygous $\left(b c /-x^{+/-} / b c l-2^{+/-}\right)$mice were raised and interbred to generate $b c l-x^{-1-} / b c l-2^{-1-}$ embryos. Wildtype $\left(b c /-x^{+/+} / b c l-2^{+/+}\right)$and $b c l-2$-deficient $\left(b c l-x^{+/+} / b c l-2^{-/-}\right)$ cultures grown in DMEM did not contain differing amounts of apoptosis (Figure 3A). The increased apoptosis in $b c l-x-$

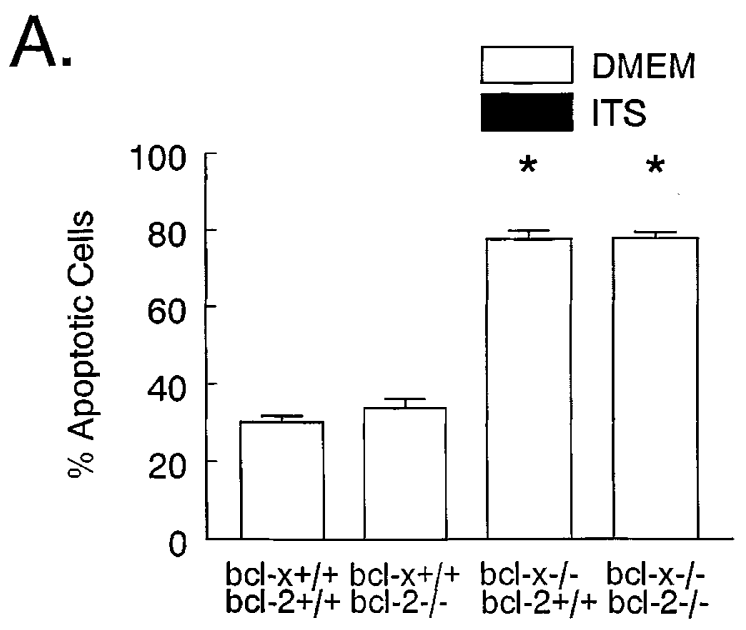

B.

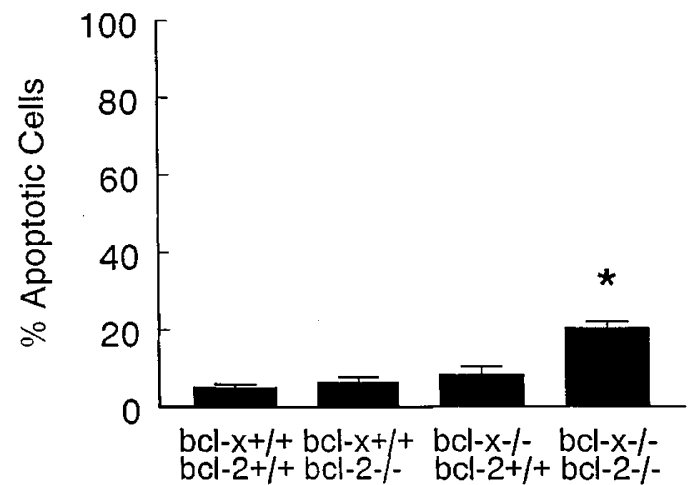

Figure 3 Disruption of $b c l-2$ increases apoptosis in $b c l-x$-deficient cultures grown in ITS. (A) Disruption of $b c /-2$ does not enhance apoptosis in $b c l-x^{+/+}$or $b c l-x^{-l-}$ E12 telencephalic cultures grown in DMEM. Statistical significance $(P \leqslant 0.05)$ is represented by * for comparisons to wild-type $\left(b c l-x^{+/+} / b c /-2^{+/+}\right)$ cultures. (B) Disruption of $b c l-2$ attenuates protective effects of ITS in $b c l-x$ deficient E12 telencephalic cultures. Statistical significance $(P \leqslant 0.05)$ is represented by * for comparisons to wild-type $\left(\mathrm{bcl}-x^{+/+} / b c /-2^{+/+}\right)$cultures. Data show the mean \pm SEM percentage of apoptotic cells in cultures generated from four $b c /-x^{+/+} / b c l-2^{+/+}$embryos, five $b c /-x^{+/+} / b c l-2^{-1-}$ embryos, four $b c l-x^{-1-} / b c l-2^{+/+}$embryos, and five $b c l-x^{-1-} \mid b c l-2^{-1-}$ embryos deficient $\left(b c l-x^{-/-} / b c l-2^{+/+}\right)$cultures was also observed in double-deficient $\left(b c /-x^{-1-} / b c l-2^{-1-}\right)$ cultures (Figure $\left.3 \mathrm{~A}\right)$. Furthermore, apoptosis in cultures generated from mice carrying a single copy of either $b c l-x$ or $b c l-2$ did not differ as compared to cultures from mice carrying two copies of the respective gene (data not shown).

Cultures grown in ITS contained significantly fewer apoptotic cells than those grown in DMEM (Figure 3). In ITS, the number of apoptotic cells was not different in cultures generated from $b c /-x^{+/+} / b c l-2^{+/+}, b c l-x^{+/+} / b c l-2^{-/-}$, or $b c l-x^{-1-} / b c l-2^{+/+}$mice (Figure 3B). Although ITS significantly reduced apoptosis in $b c /-x^{-1-} / b c l-2^{-1-}$ cultures as compared to cultures grown in DMEM, survival promoting effects of ITS were attenuated by disruption of $b c l-2$. Cultures of $b c l-x^{-1-} / b c l-2^{-1-}$ cells grown in ITS contained significantly more apoptotic cells than either wild-type or $b c /-x^{-/-}$, $b c /-2^{+/+}$cultures (Figure $3 \mathrm{~B}$ ), indicating $b c /-2$ expression contributes to the $\mathrm{Bcl}-\mathrm{x}_{\mathrm{L}}$ independent survival pathway observed in $b c /-x^{-1-}$ telencephalic cells grown in ITS.

\section{The ratio of bcl-2 to bax is increased in E12 telencephalic cultures grown in ITS}

The reduced ability of ITS to promote survival of $b c /-x^{-1-}$ cells lacking $b c /-2$ suggests that ITS may exert its effects by regulating expression of $b c /-2$ family members. Expression of the anti-apoptotic bcl-2 gene and the pro-apoptotic bax gene was examined. bax has been shown previously to interact with $b c l-x$ to promote survival of E12 telencephalic cultures (Shindler et al, 1997). Levels of bcl-2 and bax mRNA were compared by semi-quantitative RT - PCR using the constitutively expressed cyclophilin gene to normalize the relative amount of mRNA in each culture. In both wild-type (Figure 4A) and $b c /-x^{-1-}$ (Figure 4B) cultures, cyclophilin expression was higher in cultures treated with ITS as compared to cultures grown in DMEM, reflecting increased cell survival in enriched medium. In wild-type cultures, ITS increased the ratio of $b c /-2$ to bax mRNA to $1.35 \pm 0.08$ that of cells grown in basal medium (from six embryos, $P \leqslant 0.05$ ) (Figure 4A). An increased ratio of $b c l-2$ to bax expression (1.44 \pm 0.09$)$ was also observed for $b c l-x^{-1-}$ cells grown in ITS versus DMEM (three embryos, $P \leqslant 0.05$ ) (Figure 4B), suggesting that ITS alters $b c l-2$ and bax expression independent of the $b c l-x$ gene. Interestingly, although an increased ratio of $b c /-2$ to bax expression was observed in both wild-type and $b c /-x^{-1-}$ cells grown in ITS, wild-type cells contained decreased expression of both $b c l-2$ and bax in ITS versus DMEM $(P \leqslant 0.05)$ $(75.8 \pm 6.7 \%$ and $56.1 \pm 3.5 \%$ for bcl-2 and bax, respectively). $b c /-x^{-1-}$ cells, however, showed no change in $b c /-2$ expression $(P \geqslant 0.05)$ but decreased bax expression $(P \leqslant 0.05) \quad(104.8 \pm 12.3 \%$ and $73.5 \pm 8.7 \%$, respectively). Expression of $b c /-x$ mRNA was not significantly altered by ITS in wild-type cultures $(P \geqslant 0.05)(87 \pm 16 \%)$, nor was it detected in $b c l-x^{-1-}$ cultures (Figure 4$)$.

\section{E12 telencephalic cell survival is not regulated by Bad}

In addition to $\mathrm{Bcl}-\mathrm{x}, \mathrm{Bcl}-2$, and $\mathrm{Bax}$, other members of the $\mathrm{Bcl}-$ 2 family may balance with these members to affect survival of 


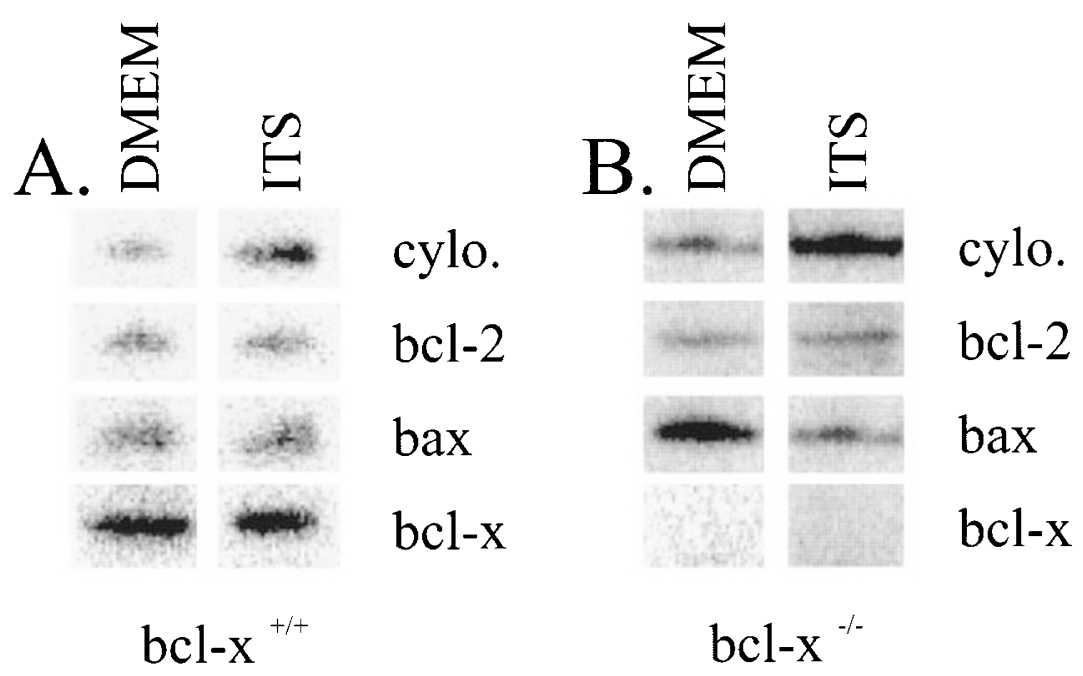

Figure 4 Analysis of $b c /-2$ family mRNAs in $E 12$ telencephalic cells by reverse transcriptase polymerase chain reaction. Wild-type $\left(b c l-x^{+/+}\right)(\mathbf{A})$ and $b c /-x_{-}$ deficient $\left(b c l-x^{-l-}\right)$ cells (B) were grown in DMEM or ITS, RNA was isolated, and cDNA was prepared. Cyclophilin and bcl-2 family mRNAs were amplified by PCR; products were separated on polyacrylamide gels, and visualized by autoradiography and phosphorimaging using ImageQuant software from Molecular Dynamics. Results shown are from single experiments and are representative of results observed from six $b c /-x^{+/+}$and three $b c /-x^{-/-}$embryos

telencephalic cells. In some cell types, Bad heterodimerizes with Bcl- $\mathrm{x}_{\mathrm{L}}$ and inhibits its anti-apoptotic effects (Yang et al, 1995). To determine if Bad regulates apoptosis of $E 12$ telencephalic cells, cultures of wild-type, heterozygous, and bad-deficient cells were grown for $48 \mathrm{~h}$ in DMEM. No difference in apoptosis was found between $\mathrm{bad}^{+/+}$(eight embryos), bad $^{+/-}$(13 embryos), or bad ${ }^{-/-}$(seven embryos) cultures $(P \geqslant 0.05$; Figure 5).

\section{Discussion}

The ability of ITS and FCS-supplemented DMEM to inhibit apoptosis of E12 telencephalic cells (Roth et al, 1996; and this study) indicates that factors present in these media promote survival of immature telencephalic cells. Since ITS contains a high concentration of insulin, it was hypothesized that insulin was important in mediating cell survival. This study demonstrates that insulin and insulin-like molecules IGF-I and IGF-II can inhibit apoptosis of E12 telencephalic cells. These results are supported by other studies illustrating that both IGF-I and IGF-II promote survival in many neuronal systems (Lindholm et al, 1996; D'Mello et al, 1993; Neff et al, 1993; Aizenman and de Vellis, 1987). The mechanism by which IGF-I mediates effects in other systems involves IGF-I receptor activation and PI3K pathways (Singleton et al, 1996a,b; Matthews and Feldman, 1996; D'Mello et al, 1997), and results presented here indicate a similar mechanism is used by immature telencephalic cells. IGF-I, IGF-II, and IGF-I receptors are expressed in the CNS by the early developmental period studied (Bondy et al, 1990; Rotwein et al, 1988), and activation of IGF-I receptors may therefore promote survival of immature telencephalic cells in vivo.

Although IGF receptor ligands reduced cell death, apoptosis was not reduced to the same extent as it was

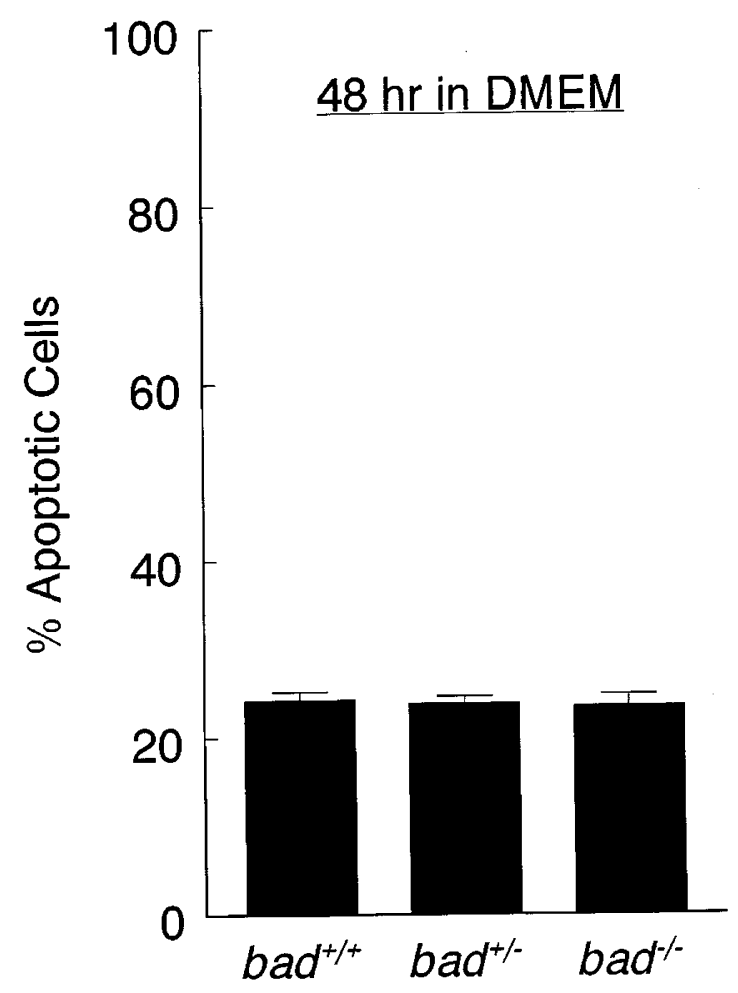

Figure 5 bad deficiency does not alter apoptosis of E12 telencephalic cells. Wild-type $\left(\mathrm{bad}^{+/+}\right)$, heterozygous $\left(\mathrm{bad}^{+/-}\right)$, and bad-deficient $\left(\mathrm{bad}^{-/-}\right)$ telencephalic cells were isolated on E12 and grown for $48 \mathrm{~h}$ in DMEM. Cells were fixed, stained with bisbenzimide, and the number of abnormal, apoptotic nuclei was counted as a percentage of the total number of nuclei present $(\%$ apoptotic cells). No differences in apoptosis were found between $\mathrm{bad}^{+/+}(n=8)$, bad $^{+/-}(n=13)$, or bad ${ }^{-1-}(n=7)$ cultures $(P \geqslant 0.05)$ 
by ITS or FCS, suggesting that additional factors may also promote telencephalic cell survival. A number of other factors, including NGF, BDNF, NT-3, NT-4/5, CNTF, GDNF, and EGF promote neuronal survival and differentiation in distinct cell populations. Specific effects on embryonic telencephalic cell populations have been reported. For example, BDNF promotes survival of primary cortical neurons in vitro (Ghosh et al, 1994), and NT-4/5 causes increased survival of developing striatal neurons (Garcia et al, 1992; Ardelt et al, 1994). The inability of these factors to promote survival in the present study may reflect the fact that few studies have used telencephalic cells isolated as early as E12. Furthermore, in many studies telencephalic cells were grown in FCS- or ITS-supplemented media prior to assessment of the effects of neurotrophic factors. Previously reported neurotrophic factor responsiveness may be a property of maturing neurons. Addition of FCS or ITS may promote survival of precursor cells in vitro, resulting in differentiation and eventual responsiveness to neurotrophic factors. The failure of neurotrophic factors to rescue $\mathrm{E} 12$ telencephalic cells in the current study may therefore indicate that neural precursors and/or progenitor cells have not yet developed the ability to respond to these factors.

The increased death of $b c l-x^{-1-}$ telencephalic cells as compared to wild-type cells demonstrates that these cells are kept alive by a pathway which is dependent on $\mathrm{Bcl}-\mathrm{x}_{\mathrm{L}}$. The ability of IGF receptor ligands and enriched media to promote survival of $b c /-x^{-l-}$ cells, however, indicates these factors can stimulate at least one $\mathrm{Bcl}-\mathrm{x}_{\mathrm{L}}$ independent anti-apoptotic pathway. It has been shown that Bax interacts with $\mathrm{Bcl}-\mathrm{x}_{\mathrm{L}}$ to regulate telencephalic cell survival in the $\mathrm{Bcl}-\mathrm{x}_{\mathrm{L}}$ dependent pathway (Shindler et al, 1997), but the potential role of other Bcl-2 family members in promoting $\mathrm{Bcl}-\mathrm{x}_{\mathrm{L}}$ independent survival was not known. Death of immature telencephalic cells by both $\mathrm{Bcl}-\mathrm{x}_{\mathrm{L}}$ dependent and independent pathways is mediated by members of the caspase family of cysteine proteases (Roth and Shindler, 1998). Furthermore, this death occurs by an apoptotic process as evidenced not only by caspase activation, which occurs during apoptosis but not during necrosis (Armstrong et al, 1997), but also by nuclear condensation and terminal deoxytransferase-mediated deoxyuridine triphosphate nick end-labeling (Shindler et al, 1997; Roth et al, 1996), previously used markers of apoptosis (Deckwerth and Johnson, 1993; Gavrieli et al, 1992). Results here indicate that trophic factor signaling can indeed prevent this apoptotic process even in the absence of $\mathrm{Bcl}-\mathrm{x}_{\mathrm{L}}$.

IGF-I signaling through the IGF-I receptor and PI3K may promote telencephalic cell survival through a pathway that is completely independent of the Bcl-2 family. Alternatively, this signaling pathway may directly regulate $\mathrm{Bcl}-2$ gene family members. Furthermore, although ITS mediated survival was observed to be partially dependent on the IGF-I receptor and PI3K, ITS continued to exert a significant survival effect in the presence of $\alpha-\mathrm{IR}_{3}$ or wortmannin. Additional signaling pathways activated by ITS may circumvent the role of the Bcl-2 family or may directly regulate $\mathrm{Bcl}-2$ family members. Although a signaling pathway that promotes survival by directly inhibiting the cell death machinery is most consistent with preventing death in response to an acute stimulus, the alternative hypothesis that ITS may also use a longer process of regulating $b c /-2$ gene family member expression needs to be considered. In the paradigm used in these studies, apoptosis occurs approximately $30 \mathrm{~h}$ after initial plating of cells, whereas the ITS media is added at time zero. This may provide sufficient time for ITS to alter gene expression and thereby affect the susceptibility of a cell to an apoptotic signal.

Members of the Bcl-2 family form homo- and heterodimers (Sato et al, 1994; Chittenden et al, 1995; Yin et al, 1994; Sedlak et al, 1995), and the intracellular balance between pro- and anti-apoptotic members may ultimately determine the fate of a cell in response to a given signal (Krajewski et al, 1995; Oltvai and Korsmeyer, 1994; Oltvai et al, 1993; Sedlak et al, 1995). For example, the ratio of anti-apoptotic $\mathrm{Bcl}-\mathrm{x}_{\mathrm{L}}$ to pro-apoptotic Bax protein is important in regulating immature telencephalic neuron survival (Shindler et al, 1997). The ability of ITS, insulin, and IGFs to reduce apoptosis of $b c l-x^{-1-}$ telencephalic cells therefore suggests that these factors may act to restore a favorable intracellular balance of $\mathrm{Bcl}-2$ family members. IGF-I does alter levels of some Bcl-2 family proteins in cultured neuroblastoma cells (Singleton et al, 1996a), indicating insulin-like molecules can alter the intracellular balance of Bcl-2 family members in some systems, although Bcl-2 family expression is not affected in other cell types rescued by IGF-I (Xu et al, 1997; Jung et al, 1996).

The ability of ITS to promote E12 telencephalic cell survival in the absence of $b c /-x$ depends, in part, on $b c /-$ 2 expression. Although ITS attenuated apoptosis in wildtype and $b c /-x^{-1-}$ cells, ITS could not prevent apoptosis of some $b c /-x^{-1-}$ cells lacking a functional $b c l-2$ gene. This result suggests that ITS requires $b c l-2$ to promote survival in at least a subpopulation of telencephalic cells, and is consistent with the possibility that ITS may restore a favorable balance between $\mathrm{Bcl}-2$ family members. In previous studies, bcl-2 deficiency showed only subtle nervous system abnormalities in vivo (Nakayama et al, 1993, 1994; Veis et al, 1993) despite the fact that $\mathrm{Bcl}-2$ is present at high levels in proliferating neuroepithelial cells (Merry et al, 1994; Novack and Korsmeyer, 1994) and overexpression of $b c l-2$ leads to increased brain weight and numbers of neurons in specific regions (Farlie et al, 1995; Martinou et al, 1994). Taken together, these results suggest $\mathrm{Bcl}-2$ plays a secondary role to $\mathrm{BCl}-\mathrm{x}_{\mathrm{L}}$ in the developing $\mathrm{CNS}$, serving a redundant function to promote survival when $b c l-x$ fails to be expressed.

Rescue of $b c l-x^{-1-} / b c l-2^{-1-}$ telencephalic cells by ITS may be reduced if ITS normally acts to up-regulate $b c /-2$. Alternatively, ITS may alter expression of other $b c l-2$ gene family members and still require functional $b c l-2$ to maintain a favorable balance of anti-apoptotic proteins. Data support the latter hypothesis because ITS decreased expression of the pro-apoptotic bax gene, without up-regulating $b c /-2$, resulting in a small, yet significant increase in the ratio of 
$b c l-2$ to bax. In previous studies, the ratio of $b c l-2$ to bax was shown to directly correlate with cell survival (Oltvai et al, 1993); therefore, an increased $b c l-2$ to bax ratio may represent one mechanism by which ITS promotes telencephalic cell survival.

The relative proportion of bax decreased in both wildtype and $b c /-x^{-1-}$ cells, suggesting changes in bax resulted from treatment with ITS, rather than a cellular response to loss of $b c l-x$. The observation that bax is down-regulated by ITS assumes that levels of cyclophilin, a constitutively-active gene routinely used (Estus et al, 1994), remains constant within individual cells. Decreased levels of cyclophilin observed in DMEM versus ITS treated cultures may reflect the fact that many cells grown in DMEM were apoptotic. Unlike other systems used to study apoptosis, apoptotic cells in these low density telencephalic cultures are not removed by phagocytosis. As a result, the total number of cells does not change during the culture period such that DMEM and ITS cultures contain equivalent total cell numbers (Shindler et al, 1997). Because apoptotic cells have reduced mRNA synthesis (Johnson et al, 1996; Deckwerth and Johnson, 1993), the uncleared apoptotic cells in DMEM cultures most likely contribute reduced amounts of mRNA. Therefore, changes in expression observed in the current studies probably represent mRNA levels in viable cells, and strongly suggests that ITS can regulate $b c l-2$ family expression.

Although ITS promoted a statistically significant increase in the ratio of $b c l-2$ to bax, this change was still relatively small compared to the changes in this ratio seen to affect survival in other cell populations (Oltvai et al, 1993). The ability of ITS to regulate $\mathrm{Bcl}-2$ family expression in immature telencephalic cells therefore may only partially, if at all, contribute to its survival promoting ability. Furthermore, the current studies focused mainly on the expression of $b c l-x, b c l-2$, and bax because previous studies of expression and function have indicated roles for these family members in the developing telencephalon. The possible role of other Bcl-2 family proteins could further alter the balance between pro- and anti-apoptotic members. One such member, Bad, has been shown to block the anti-apoptotic function of $\mathrm{Bcl}-\mathrm{x}_{\mathrm{L}}$ in some cell types (Yang et al, 1995). Bad does not, however, appear to be involved in regulating immature telencephalic cell survival because targeted disruption of bad did not cause any changes in apoptosis. Although a growing number of additional Bcl-2 family members have been identified, expression studies have not examined whether most of these genes are expressed in the E12 telencephalon. The current data presented indicate that ITS can at least affect expression of some $b c /-2$ family genes, and the overall effects on the balance between all family members will have to be addressed as new members are found to be expressed and play a role in the developing telencephalon.

In summary, E12 telencephalic cells used in this study represent a population of neural precursor cells and immature neurons that have not yet innervated target tissues. Thus, extensive PCD occurring during this early development does not result from competition for targetderived trophic factors. Results of this study suggest that these early cells may depend on non-target-derived trophic factors. The IGFs represent one family that mediates these effects, and does so by promoting a $\mathrm{BCl}-\mathrm{x}_{\mathrm{L}}$ independent survival pathway.

\section{Materials and Methods}

\section{Trophic factors}

Human recombinant IGF-I, IGF-II, and insulin, and purified EGF from mouse submaxillary glands were purchased from Sigma, St. Louis, MO, USA. Purified NGF $2.5 S$ from mouse submaxillary glands and human recombinant GDNF were purchased from Alomone Labs, Jerusalem, Israel. Human recombinant CNTF, BDNF, NT-3, and NT-4 were generous gifts from Regeneron Pharmaceuticals, Tarrytown, NY, USA.

\section{Generation and detection of $b c /-x-, b c l-2-$ and bad-deficient mice}

The use of homologous recombination in ES cells to generate $b c l-x^{-1-}$ (Motoyama et al, 1995) and $b c l-2^{-1-}$ (Nakayama et al, $1993,1994)$ mice has been described previously. bad ${ }^{-1-}$ mice were also generated by homologous recombination in ES cells. bcl- $x^{+/-}$ male and female mice were bred to generate wild-type, heterozygous, and $b c l-x^{-1-}$ embryos, and endogenous and disrupted genes were detected by PCR analysis of tail DNA extracts (Shindler et al, 1997). Similarly, $\mathrm{bad}^{+/-}$male and female mice were bred to generate wildtype, heterozygous, and bad $^{-1-}$ embryos, and endogenous and disrupted genes were detected by PCR. To generate $b c l-x^{-1-} / b c l-$ $2^{-1-}$ mice, heterozygous $b c l-x^{+l-}$ and $b c l-2^{+1-}$ were first bred to yield $b c l-x^{+l-} / b c l-2^{+l-}$ double heterozygotes that were subsequently interbred. Endogenous and disrupted $b c l-2$ were also detected by PCR of tail DNA extracts (Nakayama et al, 1993).

\section{Primary telencephalic cultures}

E12 telencephalic cells were dissociated as described previously (Shindler and Roth, 1996). In short, embryos were removed on gestational day 12, telencephalic vesicles were isolated, and cells were dissociated in $0.01 \%$ trypsin with $0.004 \%$ EDTA (Sigma) and $0.001 \%$ deoxyribonuclease I (Sigma), followed by mild trituration with a fire-polished Pasteur pipette. Cells were washed and resuspended in basal media [DMEM; a 1:1 mix of Dulbecco's Modified Eagle Medium and Ham's F12 Medium (Life Technologies, Grand Island, NY, USA) with $14 \mathrm{mM}$ sodium bicarbonate and $15 \mathrm{mM}$ HEPES, pH 7.4].

Twenty-thousand cells were plated in each well of a 48 well tissue culture plate. Wells were precoated with $0.1 \mathrm{mg} \mathrm{ml}^{-1}$ poly-L-lysine (Sigma) and $0.1 \mathrm{mg} \mathrm{ml}^{-1}$ laminin (Sigma) prior to plating. Cells were incubated for $48 \mathrm{~h}$ in $5 \% \mathrm{CO}_{2}$ at $37^{\circ} \mathrm{C}$ in DMEM alone, DMEM supplemented with neurotrophic factors or $1 \%$ FCS, or in ITS media [DMEM supplemented with $5 \mu \mathrm{g} \mathrm{ml}^{-1}$ insulin, $100 \mu \mathrm{g} \mathrm{ml}^{-1}$ transferrin, $30 \mathrm{nM}$ selenium, $20 \mathrm{nM}$ progesterone, $100 \mu \mathrm{M}$ putrescine, $6 \mathrm{~g} / \mathrm{L}$ glucose, and $2 \mathrm{mM}$ glutamine (all chemicals from Sigma)]. For signaling studies, $2 \mu \mathrm{g} \mathrm{ml}^{-1} \alpha-\mathrm{IR}_{3}$ (Oncogene Research Products, Cambridge, MA, USA) or $100 \mu \mathrm{M}$ wortmannin (Sigma) was added to the culture media at the time of plating. 


\section{Bisbenzimide labeling and quantification of apoptosis}

After $48 \mathrm{~h}$ in vitro, cells were fixed for $20 \mathrm{~min}$ at room temperature in PBS with $4 \%$ paraformaldehyde. Cell nuclei were stained with a $0.04 \mu \mathrm{g} \mathrm{ml}^{-1}$ solution of bisbenzimide (Hoechst dye 33258; Sigma) in PBS. Cell counts were done as previously described (Shindler et al, 1997). Briefly, numbers of total nuclei and abnormally condensed fragmented (apoptotic) nuclei were counted in four random fields at $40 \times$ magnification for each well, and duplicate wells were counted for each culture condition. The percentage of apoptotic cells was calculated by dividing the number of apoptotic nuclei by the tota number of nuclei. Significance was established using Kruskal-Wallis analysis of variance followed by Dunn's test for all pairwise multiple comparisons.

\section{Isolation of total RNA}

Total RNA was isolated using Ultraspec ${ }^{T M}$ RNA isolation system (Biotecx Laboratories, Houston, TX, USA). After $48 \mathrm{~h}$ in vitro, plates were placed on ice and medium was gently aspirated and replaced with $300 \mu$ l Ultraspec ${ }^{\text {TM }}$ RNA solution. Cells were lysed by trituration through a pipette tip. Lysates were transferred to $1.5 \mathrm{ml}$ Eppendorf tubes on ice and lysates from duplicate cell cultures were combined (such that 40000 cells were used in each condition). After 5 min, $120 \mu \mathrm{l}$ chloroform was added to each tube, samples were mixed vigorously and incubated on ice for $5 \mathrm{~min}$. Samples were spun $15 \mathrm{~min}$ at 13500 r.p.m. at $4^{\circ} \mathrm{C}$ and each aqueous phase was transferred to a new tube. RNA was precipitated with an equal volume of isopropano for $\geqslant 1 \mathrm{~h}$ at $-20^{\circ} \mathrm{C}$. RNA was pelleted at 13500 r.p.m. for $15 \mathrm{~min}$, then washed twice with $70 \% \mathrm{EtOH}$. After the final wash, RNA was resuspended in $50 \mu \mathrm{l}$ DEPC-treated water and stored at $-80^{\circ} \mathrm{C}$ until used.

\section{Semi-quantitative reverse-transcriptase polymerase chain reaction (RT-PCR)}

cDNA was generated from $25 \mu$ l of each RNA sample using Ready-To$\mathrm{Go}^{\mathrm{TM}}$ You-Prime First-Strand beads (Pharmacia, Uppsala, Sweden) following manufacturer's instructions. After heating RNA for $10 \mathrm{~min}$ at $65^{\circ} \mathrm{C}$, samples were chilled to $4^{\circ} \mathrm{C}$. Samples were then transferred to a tube with a Ready-To-Go bead containing Moloney Murine Leukemia Virus Reverse Transcriptase. After addition of $0.2 \mu \mathrm{g}$ random hexamer primers (Boehringer Mannheim, Indianapolis, IN, USA), cDNA was synthesized at $37^{\circ} \mathrm{C}$ for $60 \mathrm{~min}$.

The $b c l-2$, bax, and $b c l-x$ primer sequences were identical to those used previously (Greenlund et al, 1995) and generated 231, 129 and 337 bp products, respectively. The cyclophilin forward (5'GGGTTCCTCCTTTCACAGA-3') and reverse (5'-GCCATCCAGCCATTCAGTC-3') primers yielded a $226 \mathrm{bp}$ fragment. Each PCR reaction used $0.8 \mu \mathrm{l}$ of $\mathrm{CDNA}$ in a $20 \mu \mathrm{l}$ solution containing $10 \mathrm{mM}$ Tris- $\mathrm{HCl}, \mathrm{pH} 8.3 ; 50 \mathrm{mM} \mathrm{KCl} ; 1.5 \mathrm{mM} \mathrm{MgCl} 2 ; 0.1 \mathrm{mM}$ each of dATP, dGTP, and dTTP; $0.05 \mathrm{mM}$ dCTP; $0.5 \mu \mathrm{Ci}\left[\alpha^{-32} \mathrm{P}\right]$-dCTP (NEN Life Sciences, Boston, MA, USA); and 0.4 U Taq polymerase (PerkinElmer, Norwalk, CT, USA), final concentrations. Each reaction also contained $2 \mu \mathrm{M}$ cyclophilin primers or $0.8 \mu \mathrm{M}$ bax, bcl-2, or $b c l-x$ primers. After a hot start at $94^{\circ} \mathrm{C}$ for $1 \mathrm{~min}$, reactions were cycled at $94^{\circ} \mathrm{C}$ for $1 \mathrm{~min}, 62^{\circ} \mathrm{C}$ for $1 \mathrm{~min}$, and $72^{\circ} \mathrm{C}$ for $1 \mathrm{~min}$. The number of PCR cycles was chosen so that product formation remained within a linear range (Freeman et al, 1994; Estus et al, 1994). Cyclophilin was amplified for 22 cycles, bcl-2 for 27 cycles, bax for 25 cycles, and bcl$x$ for 27 cycles in a Perkin-Elmer GeneAmp PCR System 2400. PCR products were separated on an $8 \%$ polyacrylamide gel, dried, and visualized on a Phosphorlmager using ImageQuant software for volume integration (Molecular Dynamics, Sunnyvale, CA, USA). Changes in the ratios of $b a x, b c l-2$, or $b c l-x$ expression divided by cyclophilin expression were examined by comparing ratios from DMEM cultures with products amplified from ITS cultures. Significance of changes in mRNA levels were determined using a Signed Ranks Test.

\section{Acknowledgements}

The authors thank Dr Dennis Y. Loh (Roche) for the gift of $b c l-x$-deficient mice and Regeneron Pharmaceuticals for recombinant BDNF, NT-3, NT$4 / 5$, and CNTF. We also thank Cecelia Latham and Jacquelyn McDonough for expert technical assistance and Dr Michael Thompson for assistance with the figures. This work was supported by National Institutes of Health grants NS35107 and NS35484.

\section{References}

Acklin SE and van der Kooy D (1993) Clonal heterogeneity in the germinal zone of the developing rat telencephalon. Development 118: 175-192

Aizenman $Y$ and de Vellis $J$ (1987) Brain neurons develop in a serum and glial free environment: effects of transferrin, insulin, insulin-like growth factor-I and thyroid hormone on neuronal survival, growth and differentiation. Brain Res. 406: $32-42$

Ardelt AA, Flaris NA and Roth KA (1994) Neurotrophin-4 selectively promotes survival of striatal neurons in organotypic slice culture. Brain Res. 647: 340-344

Armstrong RC, Aja TJ, Hoang KD, Gaur S, Bai X, Alnemri ES, Litwack G, Karanewsky DS, Fritz LC and Tomaselli KJ (1997) Activation of the CED3/ICE-related protease CPP32 in cerebellar granule neurons undergoing apoptosis but not necrosis. J. Neurosci. 17: 553-562

Blaschke AJ, Staley K and Chun J (1996) Widespread programmed cell death in proliferative and postmitotic regions of the fetal cerebral cortex. Development 122: $1165-1174$

Boise LH, Gonzalez-Garcia M, Postema CE, Ding L, Lindsten T, Turka LA, Mao X, Nunez G and Thompson CB (1993) $b c l-x$, a $b c l-2$-related gene that functions as a dominant regulator of apoptotic cell death. Cell 74: 597-608

Bondy CA, WernerH, Roberts CT and LeRoith D (1990) Cellular pattern of insulin-like growth factor-I (IGF-I) and type I IGF receptor gene expression in early organogenesis: comparison with IGF-II gene expression. Mol. Endocrinol. 4: $1386-1398$

Chittenden T, Flemington C, Houghton AB, Ebb RG, Gallo GJ, Elangovan B, Chinnadurai $G$ and Lutz RJ (1995) A conserved domain in Bak, distinct from BH1 and $\mathrm{BH} 2$, mediates cell death and protein binding functions. EMBO J. 14: $5589-$ 5596

Clarke PGH (1990) Developmental cell death: morphological diversity and multiple mechanisms. Anat. Embryol. 181: 195-213

Cowan WM, Fawcett JW, O'Leary DDM and Stanfield BB (1984) Regressive events in neurogenesis. Science 225: 1258-1265

Craig RW (1995) The BCL-2 gene family. Sem. Cancer Biol. 6: 35-43

D'Mello SR, Borodezt K and Soltoff SP (1997) Insulin-like growth factor and potassium depolarization maintain neuronal survival by distinct pathways: possible involvement of PI 3-kinase in IGF-1 signaling. J. Neurosci. 17: 15481560

D'Mello SR, Galli C, Ciotti T and Calissano P (1993) Induction of apoptosis in cerebellar granule neurons by low potassium: inhibition of death by insulin-like growth factor I and cAMP. Proc. Natl. Acad. Sci. USA 90: 10989-10993

Deckwerth TL and Johnson Jr EM (1993) Temporal analysis of events associated with programmed cell death (apoptosis) of sympathetic neurons deprived of nerve growth factor. J. Cell. Biol. 123: 1207-1222

Estus S, Zaks WJ, Freeman RS, Gruda M, Bravo Rand Johnson JrEM (1994) Altered gene expression in neurons during programmed cell death: identification of $c-j u n$ as necessary for neuronal apoptosis. J. Cell. Biol. 127: 1717-1727

Farlie PG, Dringen R, Rees SM, Kannourakis G and Bernard O (1995) bcl-2 transgene expression can protect neurons against developmental and induced cell death. Proc. Natl. Acad. Sci. USA 92: 4397-4401 
Frankowski H, Missotten M, Fernandez P-A, Martinou I, Michel P, Sadoul R and Martinou J-C (1995) Function and expression of the $B C l-x$ gene in the developing and adult nervous system. NeuroReport 6: 1917-1921

Freeman RS, Estus S and Johnson Jr EM (1994) Analysis of cell cycle-related gene expression in postmitotic neurons: selective induction of cyclin D1 during programmed cell death. Neuron. 12: $343-355$

Galli-Resta Land Ensini M (1996) An intrinsic time limit between genesis and death of individual neurons in the developing retinal ganglion cell layer. J. Neurosci. 16: 2318-2324

Garcia I, Martinou I, Tsujimoto Y and Martinou J-C (1992) Prevention of programmed cell death of sympathetic neurons by the $b c /-2$ proto-oncogene. Science 258 : 302-304

Gavrieli Y, Sherman Y and Ben-Sasson SA (1992) Identification of programmed cell death in situ via specific labeling of nuclear DNA fragmentation. J. Cell. Biol. 119: 493-501

Ghosh A, Carnahan J and Greenberg ME (1994) Requirement for BDNF in activitydependent survival of cortical neurons. Science 263: 1618-1623

Gonzalez-Garcia M, Garcia I, Ding L, O'Shea S, Boise LH, Thompson CB and Nunez $G$ (1995) $b c l-x$ is expressed in embryonic and postnatal neural tissues and functions to prevent neuronal cell death. Proc. Natl. Acad. Sci. USA 92: 43044308

Gonzalez-Garcia M, Perez-Ballestero R, Ding L, Duan L, Boise LH, Thompson CB and Nunez $G$ (1994) $b c l-x_{\mathrm{L}}$ is the major $b c l-x$ mRNA form expressed during murine development and its product localizes to mitochondria. Development 120: $3033-3042$

Greenlund LJS, Korsmeyer SJ and Johnson JrEM (1995) Role of Bcl-2 in the survival and function of developing and mature sympathetic neurons. Neuron 15: 649661

Homma S, Yaginuma H and Oppenheim RW (1994) Programmed cell death during the earliest stages of spinal cord development in the chick embryo: a possible means of early phenotypic selection. J. Comp. Neurol 345: 377-395

Ip NY, Boulton TG, Li Y, Verdi JM, Birren SJ, Anderson DJ and Yancopoulos GD (1994) CNTF, FGF, and NGF collaborate to drive the terminal differentiation of MAH cells into postmitotic neurons. Neuron 13: 443-455

Johnson Jr EM, Deckwerth TL and Deshmukh M (1996) Neuronal death in developmental models: possible implications in neuropathology. Brain Pathol. 6: 397-409

Jung Y-K, Miura M and Yuan J (1996) Suppression of interleukin1 $\beta$-converting enzyme-mediated cell death by insulin-like growth factor. J. Biol. Chem. 271: $5112-5117$

Knusel B, Michel PP, Schwaber JS and Hefti F (1990) Selective and nonselective stimulation of central cholinergic and dopaminergic development in vitroby nerve growth factor, basic fibroblast growth factor, epidermal growth factor, insulin and the insulin-like growth factors I and II. J. Neurosci. 10: 558-570

Krajewski S, Krajewska M, Shabaik A, Wang H-G, Irie S, Fong L and Reed JC (1994) Immunohistochemical analysis of in vivo patterns of bcl-x expression. Cancer Res. 54: 5501-5507

Krajewski S, Mai JK, Krajewska M, Sikorska M, Mossakowski MJ and Reed JC (1995) Upregulation of bax protein levels in neurons following cerebral ischemia. J. Neurosci. 15: $6364-6376$

Lance-Jones C (1982) Motoneuron cell death in the developing lumbar spinal cord of the mouse. Dev. Brain Res. 4: 473-479

Levi-Montalcini R (1966) The nerve growth factor: its mode of action on sensory and sympathetic nerve cells. Harvey Lect. 60: 217-259

Lin L-FH, Doherty DH, Lile JD, Bektesh S and Collins F (1993) A glial cell line-derived neurotrophic factor for midbrain dopaminergic neurons. Science 260: 11301132

Lindholm D, Carroll P, Tzimagiorgis G and Thoenen H (1996) Autocrine-paracrine regulation of hippocampal neuron survival by IGF-1 and the neurotrophins BDNF, NT-3, and NT-4. Euro. J. Neurosci. 8: 1452-1460

Martinou J-C, Dubois-Dauphin M, Staple JK, Rodriguez I, Frankowski H, Missotten M, Albertini P, Talabot D, Catsicas S, Pietra C and Huarte J (1994) Overexpression of Bcl-2 in transgenic mice protects neurons from naturally occurring cell death and experimental ischemia. Neuron 13: 1017-1030

Maruyama S and D'Agostino AN (1967) Cell necrosis in the central nervous system of normal rat fetuses. Neurology 17: 550-558

Matthews CC and Feldman EL (1996) Insulin-like growth factor I rescues SH-SY5Y human neuroblastoma cells from hyperosmotic induced programmed cell death. J. Cell Physiol 166: 323-331
Merry DE and Korsmeyer SJ (1997) Bcl-2 gene family in the nervous system. Annu. Rev.Neurosci. 20: 245-267

Merry DE, Veis DJ, Hickey WF and Korsmeyer SJ (1994) bcl-2 protein expression is widespread in the developing nervous system and retained in the adult PNS. Development 120: 301-311

Motoyama N, Wang F, Roth KA, Sawa H, Nakayama K-i, Nakayama K, Negishi I, Senju S, Zhang Q, Fujii S and Loh DY (1995) Massive cell death of immature hematopoietic cells and neurons in Bcl-x-deficient mice. Science 267: $1506-$ 1510

Nakayama K, Nakayama K-i, Negishi I, Kuida K, Sawa H and Loh DY (1994) Targeted disruption of $\mathrm{Bcl}-2 \alpha \beta$ in mice: occurrence of gray hair, polycystic kidney disease, and lymphocytopenia. Proc. Natl. Acad. Sci. USA 91: 3700 3704

Nakayama K-i, Nakayama K, Negishi I, Kuida K, Shinkai Y, Louie MC, Fields LE, Lucas PJ, Stewart V, Alt FW and Loh DY (1993) Disappearance of the lymphoid system in Bcl-2 homozygous mutant chimeric mice. Science 261 $1584-1588$

Neff NT, Prevette D, Houenou LJ, Lewis ME, Glicksman MA, Yin Q-W and Oppenheim RW (1993) Insulin-like growth factors: putative muscle-derived trophic agents that promote motoneuron survival. J. Neurobiol. 24: 1578-1588

Novack DV and Korsmeyer SJ (1994) Bcl-2 protein expression during murine development. Am. J. Pathol. 145: 61-73

Oltvai ZN and Korsmeyer SJ (1994) Checkpoints of dueling dimers foil death wishes. Cell 79: $189-192$

Oltvai ZN, Milliman CL and Korsmeyer SJ (1993) Bcl-2 heterodimerizes in vivo with a conserved homolog, Bax, that accelerates programed cell death. Cell 74:609_ 619

Oppenheim RW (1991) Cell death during development of the nervous system. Ann. Rev. Neurosci. 14: 453-501

Purves D (1986) The trophic theory of neural connections. Trends in Neurosci. 9: $486-489$

Reed JC (1994) Bcl-2 and the regulation of programmed cell death. J. Cell Biol. 124: $1-6$

Roth KA, Motoyama N and Loh DY (1996) Apoptosis of $b c l-x$-deficient telencephalic cells in vitro. J. Neurosci. 16: 1753-1758

Roth KA and Shindler KS (1988) Caspase regulation of telencephalic cell survival. J. Neuropath. Exp. Neurol. 57: 514 (A182)

Rotwein P, Burgess SK, MilbrandtJD and Krause JE (1988) Differential expression of insulin-like growth factor genes in rat central nervous system. Proc. Natl. Acad. Sci. USA 85: 265-269

Sato T, Hanada M, Bodrug S, Irie S, Iwama M, Boise LH, Thompson CB, Golemis E, Fong L, Wang H-G and Reed JC (1994) Interactions among members of the Bcl-2 family analyzed with a yeast two-hybrid system. Proc. Natl. Acad. Sci. USA 91 $9238-9242$

Sedlak TW, Oltvai ZN, Yang E, Wang K, Boise LH, Thompson CB and Korsmeyer SJ (1995) Multiple Bcl-2 family members demonstrate selective dimerizations with Bax. Proc. Natl. Acad. Sci. USA 92: 7834-7838

Shindler KS, Latham CB and Roth KA (1997) bax deficiency prevents the increased cell death of immature neurons in $b c l-x$-deficient mice. J. Neurosci. 17: 3112 3119

Shindler KS and Roth KA (1996) Cholera toxin binds to differentiating neurons in the developing murine basal ganglia. Dev. Brain Res. 92: 199-210

Singleton JR, Dixit VM and Feldman EL (1996a) Type I insulin-like growth factor receptor activation regulates apoptotic proteins. J. Biol. Chem. 271: 31791 31794

Singleton JR, Randolph AE and Feldman EL (1996b) Insulin-like growth factor I receptor prevents apoptosis and enhances neuroblastoma tumorigenesis. Cancer Res. 56: 4522-4529

Thomaidou D, Mione MC, Cavanagh JFR and Parnavelas JG (1997) Apoptosis and its relation to the cell cycle in the developing cerebral cortex. J. Neurosci. 17 $1075-1085$

Veis DJ, Sorenson CM, Shutter JR and Korsmeyer SJ (1993) Bcl-2-deficient mice demonstrate fulminant lymphoid apoptosis, polycystic kidneys, and hypopigmented hair. Cell 75: 229-240

WidmerHRand Hefti F (1994) Neurotrophin-4/5 promotes survival and differentiation of rat striatal neurons developing in culture. Euro. J. Neurosci. 6: 1669-1679

Wyllie AH, Kerr JFR and Currie AR (1980) Cell death: the significance of apoptosis. Intl. Rev. Cytol. 68: 251-306 
XuF, Gardner A, Tu Y, Michl P, Prager D and Lichtenstein A (1997) Multiple myeloma cells are protected against dexamethasone-induced apoptosis by insulin-like growth factors. Brit.J. Haematol. 97: 429-440

Yang E, Zha J, Jockel J, Boise LH, Thompson CB and Korsmeyer SJ (1995) Bad, a heterodimeric partner for $\mathrm{Bcl}-\mathrm{x}_{\mathrm{L}}$ and $\mathrm{Bcl}-2$, displaces $\mathrm{Bax}$ and promotes cell death. Cell 80: 285-291.
Yin X-M, Oltvai ZN and Korsmeyer SJ (1994) BH1 and BH2 domains of Bcl-2 are required for inhibition of apoptosis and heterodimerization with Bax. Nature 369 : $321-323$ 